\title{
The Alterations of Microvasculature, Tyrosine Phosphorylation, and Lipid Peroxidation in Kidney of Rats Treated with Valproic Acid
}

\author{
Alteraciones de la Microvasculatura, Fosforilación de Tirosina y Peroxidación \\ Lipídica en Riñones de Ratas Tratadas con Ácido Valproico
}

\author{
Chanwit Maneenin $^{1,2}$; Natthapol Lapyuneyong ${ }^{1}$; Saranya Tongpan ${ }^{1}$; Supataechasit Yannasithinon ${ }^{1}$; \\ Jaturon Burawat ${ }^{1}$; Naowarat Maneenin ${ }^{3}$; Wannisa Sukhorum ${ }^{4}$; Supatcharee Arun ${ }^{1} \&$ Sitthichai Iamsaard $^{1,5}$
}

MANEENIN, C.; LAPYUNEYONG, N.; TONGPAN, S.; YANNASITHINON, S.; BURAWAT, J.; MANEENIN, N.; SUKHORUM, W.; ARUN, S. \& IAMSAARD, S. The alterations of microvasculature, tyrosine phosphorylation, and lipid peroxidation in kidney of rats treated with valproic acid. Int. J. Morphol., 37(1):65-70, 2019.

SUMMARY: Valproic acid (VPA), an antiepileptic drug, has been demonstrated to damage histology and to change tyrosine phosphorylation patterns with increased oxidative stress in perirenal tissues. This study aimed to investigate the effect of VPA on microstructure, tyrosine phosphorylation, and lipid peroxidation of rat kidney. Adult male rats were divided into control and VPA-treated groups intraperitoneally injected with normal saline and VPA $500 \mathrm{mg} / \mathrm{kgBW}$ for 10 consecutive days, respectively ( $\mathrm{n}=7$ each). The blood serum was examined for biochemical levels. The kidney tissues were routinely processed for histological observation. Total proteins from kidney were extracted to assay the malondialdehyde (MDA) levels and phosphorylation expression. The results showed that VPA significantly decreased blood glucose levels while tend to increase urea nitrogen and creatinine. MDA levels in VPA group were significantly higher that of control. Renal cortex of VPA-treated animals revealed vasodilatations. Although the ratio of a renal phosphorylated $72 \mathrm{kDa}$ protein/ beta actin expression seemed to be not different in both groups, VPA significantly decreased the intensity of beta actin. In conclusion, VPA dilates renal microvasculature with increasing of MDA but suppresses the actin expression.

KEY WORDS: Valproic acid; Vasodilatation; Tyrosine phosphorylation; Kidney; Rats.

\section{INTRODUCTION}

Sodium valproate or valproic acid (VPA) is an antiepileptic drug which is commonly used in the treating of epileptic seizures and many brain disorders (Löscher, 2002; Gelder et al., 2006). Although VPA posses many therapeutic properties including anti cancers (Gelder et al.; Berendsen et al., 2012; Glister et al., 2012), its side effects have also been reported previously. VPA has been shown to cause congenital malformations (Jentink et al., 2010; Witczak et al., 2010), adenocarcinomas of the female reproductive tract (Watkins et al., 1992), sex hormone disorders (Sveberg Røste et al., 2002; Bauer et al., 2004; Isojärvi et al., 2004; Herzog et al., 2004; Isojärvi, 2008; Taubøll et al., 2008), male reproductive tissue damages (Hamza \& Amin, 2007; Krogenaes et al., 2008; Vijay-Kumar et al., 2010; Iamsaard et al., 2017a,b; Sukhorum \& Iamsaard,
2017). Moreover, VPA has been documented to affect the kidney at both biochemical and histological levels (ElShenawy \& Hamza, 2016). Recently, it was reported that VPA induces the kidney proximal tubular injury and renal failure contributed by mitochondrial dysfunction and oxidative stress (Heidari et al., 2018).

Protein tyrosine phosphorylation is a posttranslational process important for the cell proliferations, divisions, and differentiations in normal and cancer/ abnormal cells of many mammal tissues (Hunter, 1987; Hanks et al., 1988; Ullrich \& Schlessinger, 1990; Arun et al., 2016a,b; Sukhorum \& Iamsaard). Such tyrosine phosphorylated proteins are clearly demonstrated to be localized in highly division tissue such as seminiferous epithelium (Chaichun et al., 2017). Indeed,

\footnotetext{
${ }^{1}$ Department of Anatomy, Faculty of Medicine, Khon Kaen University, Khon Kaen, 40002, Thailand.

${ }^{2}$ College of Medicine and Public Health, Ubon Ratchathani University, Ubon Ratchathani, 34190, Thailand.

${ }^{3}$ Department of Epidemiology and Biostatistics, Faculty of Public Health, Khon Kaen University, 40002, Thailand.

${ }^{4}$ School of Medicine, Mae Fah Luang University, Chiang Rai, 57100, Thailand.

${ }^{5}$ Center for Research and Development of Herbal Health Product, Faculty of Pharmaceutical Sciences, Khon Kaen University, 40002, Thailand.
} 
MANEENIN, C.; LAPYUNEYONG, N.; TONGPAN, S.; YANNASITHINON, S.; BURAWAT, J.; MANEENIN, N.; SUKHORUM, W.; ARUN, S. \& IAMSAARD, S. The alterations of microvasculature, tyrosine phosphorylation, and lipid peroxidation in kidney of rats treated with valproic acid. Int. J. Morphol., 37(1):65-70, 2019.

VPA is shown to alter the protein tyrosine phosphorylation especially in the reproductive system (Arad-Dann et al., 1993; Iamsaard et al., 2014; Iamsaard et al., 2015; Sukhorum et al., 2016; Iamsaard et al., 2017a,b; Sukhorum \& Iamsaard; Maneenin et al., 2018). In this issue, the changes of such process in VPA treated animal models have never been elucidated. We, therefore, aimed to not only investigate the effect of VPA on renal function and microstructure but also on tyrosine phosphorylation.

\section{MATERIAL AND METHOD}

Animals and experimental design: The male Wistar rats (6-8 weeks) were purchased from the National Laboratory Animal Center, Salaya, Nakhon Pathom province, Thailand. Animals were transferred and housed $\left(23 \pm 2{ }^{\circ} \mathrm{C}, 350-400\right.$ Lux, 30-60 \% of relative humidity and under a $12 \mathrm{~h}$ light/ dark cycle) at the Northeast Laboratory Animal Center, Khon Kaen University, Thailand. Samples were collected from rats in control and VPA groups (intraperitoneally injected with VPA500 mg/kgBW for 10 consecutive days) under an animal ethic approved project of Dr. Chanwit Maneenin (IACUC-KKU-1/B1).

Histology: Right kidney was immediately collected and fixed in $10 \%$ formalin. The fixed kidney was embedded in paraffin, sectioned at 5-7 mm thicknesses, and stained with hematoxylin and eosin. Kidney sections were observed and captured by a Nikon light ECLIPSE E200 microscope equipped with a DXM1200 digital camera.

Serum collection and biochemical assays: Blood was collected by cardiac puncture. The blood was centrifuged at $5000 \mathrm{r} / \mathrm{min}$ at $4{ }^{\circ} \mathrm{C}$ for $10 \mathrm{~min}$. The plasma glucose, blood urea nitrogen, and creatinine were assayed by hexokinase, enzyme Kinetic Urease/GLDH, enzymatic method, respectively at the Clinical Chemistry Unit, Srinagarind Hospital, Faculty of Medicine, KKU, Thailand.

Malondialdehyde (MDA) level assay: The kidney tissues of both groups were extracted using RIPA buffer (Cell Signaling Technology, Inc., USA) containing a protease inhibitor cocktail (Sigma-Aldrich, Inc., USA) and incubated on ice. After that, it was homogenated using grinder and ultrasonic homogenizer (Microprocessor controlled 100 Watt Model). The homogenate was centrifuged. Then, the total protein concentration of the kidney supernatant was measured at absorbance of $280 \mathrm{~nm}$ using a NanoDrop ND1000 Spectrophotometer. Subsequently, the concentration of kidney MDA was measured by TBARS assay (Luangaram et al., 2007). The kidney lysate was mixed whit TBARS reagents and it was boiled in water bath. Then, the pink cooling mixture was centrifuged to separate supernatant from debris. The supernatant was measured using Microplate reader at absorbance $540 \mathrm{~nm}$. The 1,1,3,3-tetraethoxypropane (TEP) concentration between 2-200 nMol are the standard curve $\left(R^{2}=0.991\right)$. The MDA concentration was expressed as $\mathrm{nMol} \mathrm{MDA} / \mathrm{mg}$ protein.

SDS-PAGE and western blot: Left kidney was homogenized with RIPA buffer (Cell Signaling Technology Inc., USA) containing a cocktail of protease inhibitors (Sigma Inc., USA). The homogenate was centrifuged at $13,000 \mathrm{rpm}$ at $4{ }^{\circ} \mathrm{C}$ for $10 \mathrm{~min}$. Then, the total protein concentrations of the kidney lysate were measured using a NanoDrop ND-1000 Spectrophotometer (NanoDrop Technologies Inc., USA) at an absorbance of $280 \mathrm{~nm}$. To conduct sodium dodecyl sulfate-polyacrylamide gel electrophoresis (SDS-PAGE) and determine the expression of tyrosine phosphorelated protein, the total kidney proteins (100 mg) were loaded and separated on $10 \%$ SDS-PAGE. After that, separated proteins were stained with Coomassie Blue or transferred onto nitrocellulose membrane. Subsequently, the membrane was blocked with non-specific protein and incubated with anti-phosphotyrosine primary antibody [1:2000 (v/v); Millipore Co., USA] or b-actin antibody [1:2000 (v/v) dilution; Santa Cruz Biotechnology Inc., USA] at $4{ }^{\circ} \mathrm{C}$ overnight. Then, the membrane was incubated with goat anti-mouse conjugated horseradish peroxidase (HRP) secondary antibody for $1 \mathrm{~h}$ at room temperature. The antigen-antibody complex was detected by using enhanced chemiluminescence (ECL) substrate under gel doct 4 (Image Quant 400, GH Healthcare, USA). The ImageJ program (Version 1.49p) was used to measure the intensity of target proteins.

Statistical analysis: The data were analysed using SPSS version 19 . The independent t-test was used to determine the statistical significance of mean differences between experiment and control groups.

\section{RESULTS}

Weight of kidneys: After treatment for 10 consecutive days, the absolute and relative weights of kidney between control and VPA groups were significantly not different (Figs. 1A, $\mathrm{B}, \mathrm{P}>0.05)$

VPA affect vasodilation of renal vessels: Figure 2 showed representative histology of kidney in control and VPAtreated rats. It was found that renal cortex of VPA-treated animals revealed some vasodilatations (Figs. 2 B, D) as 
MANEENIN, C.; LAPYUNEYONG, N.; TONGPAN, S.; YANNASITHINON, S.; BURAWAT, J.; MANEENIN, N.; SUKHORUM, W.; ARUN, S. \& IAMSAARD, S. The alterations of microvasculature, tyrosine phosphorylation, and lipid peroxidation in kidney of rats treated with valproic acid. Int. J. Morphol., 37(1):65-70, 2019.

Absolute \& relative weights of kidney in control and VPA rats
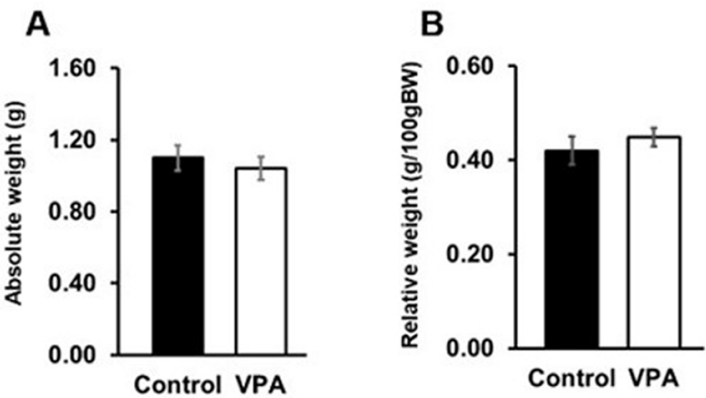

Fig. 1. Showing the absolute (A) and relative (B) weights of kidney in control and VPA-treated rats. Data are expressed as mean $\pm \mathrm{SD}$ $(\mathrm{n}=7)$.

compared to that of control (Figs. 2 A, C). However, no other cellular histopathology was observed in both groups (Fig. 2).
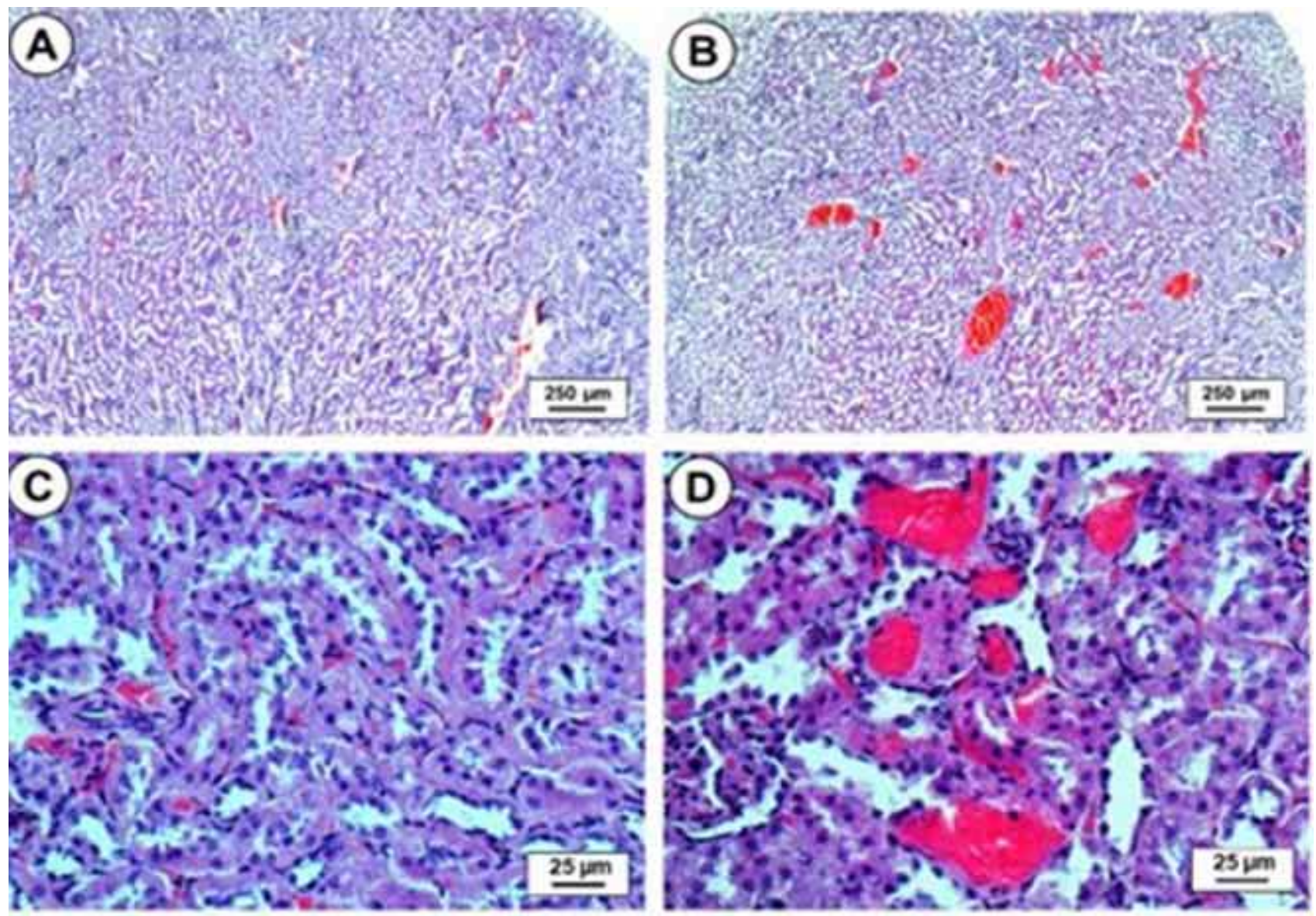

Fig. 2. Histological micrographs showing representative rat kidney stained by H\&E of control and VPA groups. Control group (A\&C; magnified from A). VPA-treated group (B\&D; magnified from B, note: some vasodilatations observed).
VPA affects serum biochemical levels: Significantly, blood glucose levels were decreased in VPA-treated rats when compared to the control (Fig. $3 \mathrm{~A}, \mathrm{P}<0.05$ ). Although blood urea nitrogen and creatinine in VPA group were tended to increase, such parameters were not different between groups (Figs. 3B, C, P>0.05)

VPA affects MDA levels: MDA is a lipidperoxidative marker present in damaged-kidney tissue. This study showed MDA level in kidney lysate of VPA-treated rat was significantly higher $(\mathrm{P}<0.05)$ than the control rats as shown in Figure 4.

Effects of VPA on renal tyrosine-phosphorylated protein and beta actin: The profiles of renal proteins performed by SDS-PAGE were used to confirm equal amounts of total proteins in triplicate control and VPA groups (Fig. 5A). The expression patterns of renal phosphorylated proteins are represented in Figure 5B. The result showed only phosphorylated $72 \mathrm{kDa}$ protein bands in both groups (Fig. $5 B)$. 
A

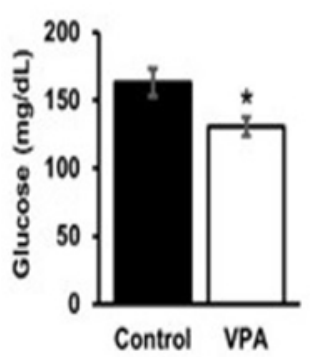

B

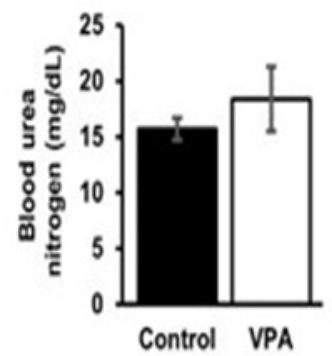

C

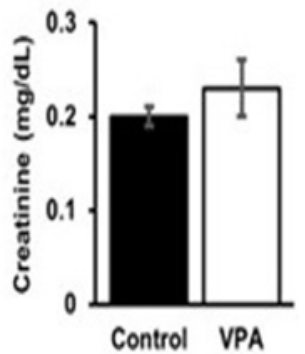

Fig. 3. Serum biochemical levels showing glucose (A), blood urea nitrogen $(\mathrm{B})$, and creatinine $(\mathrm{C})$ between control and VPA groups. *Significant differences $(\mathrm{P}<0.05)$ as compared with the control group. Data are expressed as mean $\pm \mathrm{SD}(\mathrm{n}=7)$.

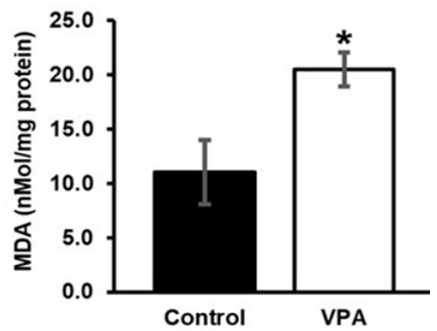

Fig. 4. Showing malondialdehyde (MDA) levels of kidney lysate in control and VPA groups using thiobarbituric acid reactive substance (TBARS) assay.

* Significant difference $(\mathrm{P}<0.05)$ as compared with control group.

A
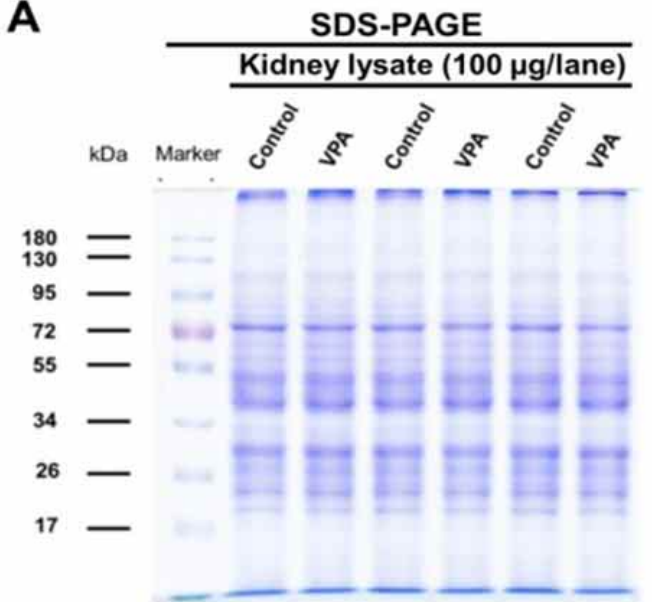

C

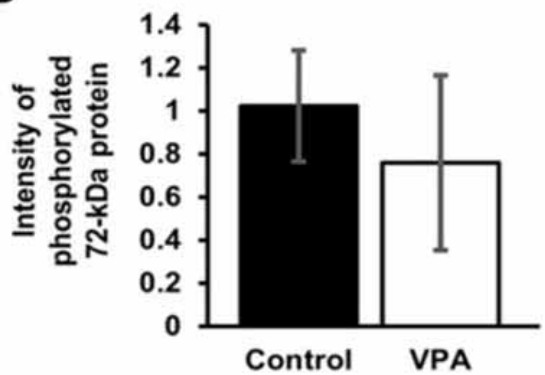

B

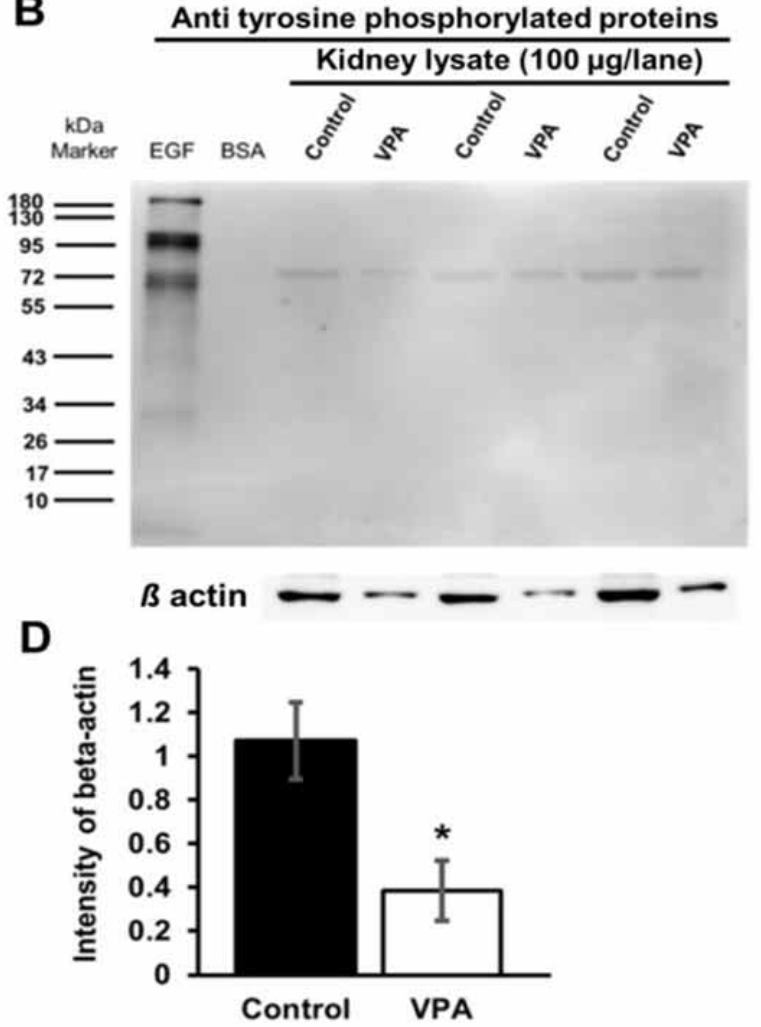

Fig. 5. Showing the equal Coomassie blue-stained protein profiles (A) and immuno-Western bolt images of tyrosine phosphorylated protein and beta actin expressions (B) in kidney of triplicate control and VPA groups. Bovine serum albumin (BSA) and epidermal growth factor (EGF)-like growth factors were used as negative and positive controls, respectively. The intensities of the 72-kDa renal phosphorylated protein (C) and beta-actin (D) between control and VPA groups. Data were represented as mean \pm S.D. $* \mathrm{P}<0.05$, compared with the control group.

In addition, the expressions of the phosphorylated protein seemed to be equal in both groups (Fig. 5B) as confirmed by its intensity (Fig. 5C). Interestingly, the expressions of beta-actin in kidney VPA groups were expressed lower than that of controls as shown in Figure 5D. This was significantly confirmed $(\mathrm{P}<0.05)$ by its intensity (Fig. 5D). 


\section{DISCUSSION}

Recently, the nephrotoxicity of VPA has been documented. VPA can damage kidney at biochemical and histological levels in adult rats (El-Shenawy \& Hamza). In an explanation of Fanconi syndrome, VPA was found to involve in mitochondrial dysfunction and oxidative stress in rat kidney (Heidari et al.). Additionally, it was reported that renal toxicity effect of VPA associated with thrombotic microangiopathy (Hebert et al., 2017). Although our study showed no difference of kidney weight between control and VPA groups, it was found that such relative weight in VPA group tended to be increased the kidney (Fig. 1 B). It is possible that VPA dilated the renal vessels resulted in increasing the blood volume in tissue (Fig. 2); however it was not enough to reach statistical significance. The levels of blood urea nitrogen and creatinine in VPA group tended to increase indicating that the VPA kidney begins to dysfunction after 10 days of experiment. However, VPA significantly decreased blood glucose levels indicating hyper glucose reabsorption in body system. To clarify this issue, the levels of glucose transporters present in renal tissues should be further investigated in both groups. Some oxidative stress markers have been reported to be altered in VPA-treated animals (Heidari et al.). Previously VPA was demonstrated to increase the MDA levels in testicular tissue with changes of protein tyrosine phosphorylation (Hamza \& Amin; Sukhorum \& Iamsaard). The tyrosine phosphorylated proteins have been postulated to play many roles in biological functions. Herein, a renal $72 \mathrm{kDa}$ phosphorylated protein expression was detected this study for the firs time and tending found to be decreased in VPA-treated rats (Fig. 5 ). It is very interesting to further identify and characterize this renal phosphorylated protein to elucidate its actual function. Interestingly, the expression of beta actin used as an internal control for protein loading in immune western blot was significantly decreased in VPA rats. However, the equal loading of renal protein lysate also was confirmed by SDS-PAGE in triplicates. Since VPA has inhibitory effect of histone deacetylase (Kanai et al., 2004), it is possible that VPA could partially suppress the beta action transcription and translation respectively. It also may be associated with increasing of MDA levels (Fig. 4) leading to disturbance of actin protein synthesis. This event is assumed that VPA begins to injure renal structure and function at day 10 of experiment.

In conclusion, our results have demonstrated the renal toxicity of VPA on vasodilatation, serum biochemical changes, and increased MDA level with low beta actin expression, respectively.
MANEENIN, C.; LAPYUNEYONG, N.; TONGPAN, S.; YANNASITHINON, S.; BURAWAT, J.; MANEENIN, N.; SUKHORUM, W.; ARUN, S. \& IAMSAARD, S. Alteraciones de la microvasculatura, fosforilación de tirosina y peroxidación lipídica en riñones de ratas tratadas con ácido valproico. Int. J. Morphol., 37(1):65-70, 2019.

RESUMEN: Se ha demostrado que el ácido valproico (AVP), un fármaco antiepiléptico, daña la histología y cambia los patrones de fosforilación de la tirosina con el aumento del estrés oxidativo en los tejidos perirrenales. Este estudio tuvo como objetivo investigar el efecto del AVP en la microestructura, la fosforilación de la tirosina y la peroxidación lipídica del riñón de rata. Se dividieron ratas macho adultas en grupos control y tratados con AVP. Durante 10 días consecutivos fueron inyectadas por vía intraperitoneal con solución salina normal y $500 \mathrm{mg} / \mathrm{kg}$ de PC respectivamente ( $\mathrm{n}=7$ cada uno). Se analizó el suero sanguíneo para determinar los niveles bioquímicos. Los tejidos renales se procesaron de forma rutinaria para la observación histológica. Las proteínas totales del riñón se extrajeron para analizar los niveles de malondialdehído (MDA) y la expresión de la fosforilación. Los resultados mostraron que el AVP disminuyó significativamente los niveles de glucosa en la sangre, mientras que tienden a aumentar el nitrógeno ureico y la creatinina. Los niveles de MDA en el grupo de AVP fueron significativamente más altos que los del control. La corteza renal de los animales tratados con AVP reveló vasodilataciones. Aunque la proporción de una expresión de proteína / actina de $72 \mathrm{kDa}$ fosforilada renal no parece ser diferente en ambos grupos, el AVP disminuyó significativamente la intensidad de la actina beta. En conclusión, el AVP dilata la microvasculatura renal al aumentar el MDA, pero suprime la expresión de actina.

PALABRAS CLAVE: Ácido valproico; Vasodilatación; Fosforilación de tirosina; Riñón; Ratas.

\section{REFERENCES}

Arad-Dann, H.; Beller, U.; Haimovitch, R.; Gavrieli, Y. \& Ben-Sasson, S. A. Immunohistochemistry of phosphotyrosine residues: identification of distinct intracellular patterns in epithelial and steroidogenic tissues. J. Histochem. Cytochem., 41(4):513-9, 1993.

Arun, S.; Burawat, J.; Sukhorum, W.; Sampannang, A.; Maneenin, C. \& Iamsaard, S. Chronic restraint stress induces sperm acrosome reaction and changes in testicular tyrosine phosphorylated proteins in rats. Int. J. Reprod. Biomed. (Yazd), 14(7):443-52, 2016a.

Arun, S.; Burawat, J.; Sukhorum, W.; Sumpannang, A.; Uabundit, N. \& Iamsaard, S. Changes of testicular phosphorylated proteins in response to restraint stress in male rats. J. Zhejiang Univ. Sci. B, 17(1):21-9, 2016 b.

Bauer, J.; Blumenthal, S.; Reuber, M. \& Stoffel-Wagner, B. Epilepsy syndrome, focus location, and treatment choice affect testicular function in men with epilepsy. Neurology, 62(2):243-6, 2004.

Berendsen, S.; Broekman, M.; Seute, T.; Snijders, T.; van Es, C.; de Vos, F.; Regli, L. \& Robe, P. Valproic acid for the treatment of malignant gliomas: review of the preclinical rationale and published clinical results. Expert Opin. Investig. Drugs, 21(9):1391-415, 2012.

Chaichun, A.; Arun, S.; Burawat, J.; Kanla, P. \& Iamsaard, S. Localization and identification of tyrosine phosphorylated proteins in adult spraguedawley rat testis. Int. J. Morphol., 35(4):1322-7, 2017. 
El-Shenawy, N. S, \& Hamza, R. Z. Nephrotoxicity of sodium valproate and protective role of L-cysteine in rats at biochemical and histological levels. J. Basic Clin. Physiol. Pharmacol., 27(5):497-504, 2016.

Gelder, M.; Harrison, P. \& Cowen, P. Shorter Oxford Textbook of Psychiatry. $5^{\text {th }}$ ed. Oxford, Oxford University Press, 2006.

Glister, C.; Satchell, L.; Michael, A. E.; Bicknell, A. B. \& Knight, P. G. The anti-epileptic drug valproic acid (VPA) inhibits steroidogenesis in bovine theca and granulosa cells in vitro. PLoS One, 7(11):e49553, 2012.

Hamza, A. A. \& Amin, A. Apium graveolens modulates sodium valproateinduced reproductive toxicity in rats. J. Exp. Zool. A Ecol. Genet. Physiol., 307(4):199-206, 2007.

Hanks, S. K.; Quinn, A. M. \& Hunter, T. The protein kinase family: conserved features and deduced phylogeny of the catalytic domains. Science, 241(4861):42-52, 1988.

Heidari, R.; Jafari, F.; Khodaei, F.; Shirazi Yeganeh, B. \& Niknahad, H. Nephrolo. Mechanism of valproic acid-induced Fanconi syndrome involves mitochondrial dysfunction and oxidative stress in rat kidney. Nephrology (Carlton), 23(4):351-61, 2018.

Herzog, A. G.; Drislane, F. W.; Schomer, D. L.; Pennell, P. B.; Bromfield, E. B.; Kelly, K. M.; Farina, E. L. \& Frye, C. A. Differential effects of antiepileptic drugs on sexual function and reproductive hormones in men with epilepsy: interim analysis of a comparison between lamotrigine and enzyme-inducing antiepileptic drugs. Epilepsia, 45(7):764-8, 2004

Hunter, T. A thousand and one protein kinases. Cell, 50(6):823-9, 1987.

Iamsaard, S.; Arun, S.; Burawat, J.; Sukhorum, W.; Boonruangsri, P.; Namking, M.; Uabundit, N.; Nualkaew, S. \& Sripanidkulchai, B. Phyllanthus emblica L. branch extract ameliorates testicular damage in valproic acid-induced rats. Int. J. Morphol., 33(3):1016-22, 2015.

Iamsaard, S.; Arun, S.; Burawat, J.; Sukhorum, W.; Wattanathorn, J.; Nualkaew, S. \& Sripanidkulchai, B. Phenolic contents and antioxidant capacities of Thai-Makham Pom (Phyllanthus emblica L.) aqueous extracts. J. Zhejiang Univ. Sci. B, 15(4):405-8, 2014.

Iamsaard, S.; Prabsattroo, T.; Sukhorum, W.; Muchimapura, S.; Srisaard, P.; Uabundit, N.; Thukhammee, W. \& Wattanathorn, J. Anethum graveolens Linn. (dill) extract enhances the mounting frequency and level of testicular tyrosine protein phosphorylation in rats. J. Zhejiang Univ. Sci. B, 14(3):247-52, 2013.

Iamsaard, S.; Sukhorum, W.; Arun, S.; Phunchago, N.; Uabundit, N.; Boonruangsri, P. \& Namking, M. Valproic acid induces histologic changes and decreases androgen receptor levels of testis and epididymis in rats. Int. J. Reprod. Biomed. (Yazd), 15(4):217-24, 2017 a.

Iamsaard, S.; Sukhorum, W.; Sampannang, A. \& Sripanidkulchai, B. Protective effect of Momordica cochinchinensis (L.) spreng aril extract on essential testicular markers in rats induced with valproic acid. Int. J. Morphol., 35(3):992-9, 2017 b.

Isojärvi, J. Disorders of reproduction in patients with epilepsy: antiepileptic drug related mechanisms. Seizure, 17(2):111-9, 2008.

Isojärvi, J. I.; Löfgren, E.; Juntunen, K. S.; Pakarinen, A. J.; Päivänsalo, M.; Rautakorpi, I. \& Tuomivaara, L. Effect of epilepsy and antiepileptic drugs on male reproductive health. Neurology, 62(2):24753, 2004.

Jentink, J.; Loane, M. A.; Dolk, H.; Barisic, I.; Garne, E.; Morris, J. K.; de Jong-van den Berg, L. T. \& EUROCAT Antiepileptic Study Working Group. Valproic acid monotherapy in pregnancy and major congenital malformations. N. Engl. J. Med., 362(23):2185-93, 2010.

Kanai, H.; Sawa, A.; Chen, R. W.; Leeds, P. \& Chuang, D. M. Valproic acid inhibits histone deacetylase activity and suppresses excitotoxicity-induced GAPDH nuclear accumulation and apoptotic death in neurons. Pharmacogenomics J., 4(5):336-44, 2004.

Krogenaes, A. K.; Taubøll, E.; Stien, A.; Oskam, I. C.; Lyche, J. L.; Dahl, E.; Thomassen, R. F.; Sweeney, T. \& Ropstad, E. Valproate affects reproductive endocrine function, testis diameter and some semen variables in non-epileptic adolescent goat bucks. Theriogenology, 70(1):15-26, 2008.
Löscher, W. Basic pharmacology of valproate: a review after 35 years of clinical use for the treatment of epilepsy. C. N. S. Drugs, 16(10):66994, 2002.

Luangaram, S.; Kukongviriyapan, U.; Pakdeechote, P.; Kukongviriyapan, V. \& Pannangpetch, P. Protective effects of quercetin against phenylhydrazine-induced vascular dysfunction and oxidative stress in rats. Food Chem Toxicol., 45(3):448-55, 2007.

Maneenin, C.; Burawat, J.; Maneenin, N.; Nualkaew, S.; Arun, S.; Sampannang, A. \& Iamsaard, S. Antioxidant capacity of Momordica charantia extract and its protective effect on testicular damage in valproic acid-induced rats. Int. J. Morphol., 36(2):447-53, 2018.

Sukhorum, W. \& Iamsaard, S. Changes in testicular function proteins and sperm acrosome status in rats treated with valproic acid. Reprod. Fertil. Dev., 29(8):1585-92, 2017

Sukhorum, W.; Sampannang, A.; Sripanidkulchai, B. \& Iamsaard, S. Momordica cochinchinensis (L.) Spreng aril extract prevents adverse reproductive parameters of male rats induced with valproic acid. Int. $J$. Morphol., 34(3):870-6, 2016.

Sveberg Røste, L.; Taubøll, E.; Isojärvi, J. I.; Pakarinen, A. J.; Huhtaniemi, I. T.; Knip, M. \& Gjerstad, L. Effects of chronic valproate treatment on reproductive endocrine hormones in female and male Wistar rats. Reprod. Toxicol., 16(6):767-73, 2002

Taubøll, E.; Røste, L. S.; Svalheim, S. \& Gjerstad, L. Disorders of reproduction in epilepsy--what can we learn from animal studies? Seizure, 17(2):120-6, 2008

Ullrich, A. \& Schlessinger, J. Signal transduction by receptors with tyrosine kinase activity. Cell, 61(2):203-12, 1990.

Vijay-Kumar, M.; Aitken, J. D.; Carvalho, F. A.; Cullender, T. C.; Mwangi, S.; Srinivasan, S.; Sitaraman, S. V.; Knight, R.; Ley, R. E. \& Gewirtz, A. T. Metabolic syndrome and altered gut microbiota in mice lacking Toll-like receptor 5. Science, 328(5975):228-31, 2010.

Watkins, R. J.; Gough, A. W.; McGuire, E. J.; Goldenthal, E. \& de la Iglesia, F. A. Calcium valproate-induced uterine adenocarcinomas in Wistar rats. Toxicology, 71(1-2):35-47, 1992.

Witczak, M.; Kociszewska, I.; Wilczyn`ski, J.; Lopaczyn`ska, D. \& Ferenc, T. Evaluation of chromosome aberrations, sister chromatid exchange and micronuclei in cultured cord-blood lymphocytes of newborns of women treated for epilepsy during pregnancy. Mutat. Res., 701(2):1117, 2010.

Corresponding author:

Dr. Sitthichai lamsaard

Department of Anatomy

Faculty of Medicine

Khon Kaen University

123 Mitraparp Road

Amphoe Muang

Khon Kaen 40002

THAILAND

Email: sittia@kku.ac.th

Received: 12-07-2018

Accepted: 14-09-2018 